\title{
Trade Liberalization and Performance of the Nigerian Textile Industry
}

\author{
Florence Oluremi Okeowo ${ }^{1}$, Rafiu Adewale Aregbeshola² \\ ${ }^{1}$ Babcock University, Ilishan Remo, Ogun State, Nigeria \\ 2University of South Africa, Pretoria, South Africa \\ okeowof@babcock.edu.ng
}

\begin{abstract}
Nigeria textile industry is characterized by questionable incentives, political uncertainty, acute power shortage, poor infrastructure, smuggling and red-tape bureaucracy, among others. The study modified the endogenous growth model within a time series (1986 and 2015) estimation techniques of Autoregressive Distributed Lagged model (ARDL). Findings revealed that the effect of simple tariff rate on textile industry is negative and statistically significant in the long-run; while trade liberalization policy measure through simple tariff rate has a lag effect before it can be effective in the textile industry. In both short and long run, real effective exchange rate depreciation worsens the performance of the textile industry in Nigeria. In the long run, a $1.0 \%$ rise in trade openness would decrease the level of textile industry performance by about $17.49 \%$, while factor affecting textile industry performance in the short run are simple tariff rate, financial development, exchange rate changes, trade openness and labor and capital inputs respectively. The study concluded that Trade liberalization has a lag effect on textile industry performance and a significant effect on the performance of the Nigerian textile industry. It is therefore recommended that government should make concerted efforts toward providing a favorable business environment, reducing inflation and improve the infrastructural facilities for the textile industry to strive.
\end{abstract}

Keywords: Trade liberalization, simple tariff rate, Industrial performance, Trade openness, Real Effective Exchange rate, Financial Development, Nigeria

\section{Introduction}

Textiles industry is an important, but often negligent sector when it comes to empirical research. The sector plays an important role in human societies be it developed or less developed and its major output, fabrics, has been established as one of the key basic need. In addition to this, textile materials are used in furniture, coverings and blinds, interiors of vehicles and health gadgets such as bandages and gloves. The textile industry is also known for its capacity to generate huge employment; hence, serving as a source of livelihood to many households. The Nigerian textile industry performed these roles as well, especially up to the 1980s and was rated third largest in Africa after Egypt and South Africa (Bello, Inyinbor, Dada and Oluyori, 2013). Nigeria's textile and apparel industry covers the clothing value chain and is characterized with questionable incentives, political uncertainty, acute power shortage, poor infrastructure, smuggling and red-tape bureaucracy, among others (Banjoko et al., 2012; Eneji et al., 2012; Maiwada and Renne, 2013). However, the government of Nigeria in appreciation of the role of industrialization in growth process now motivates firms. This is done through the establishment of various agencies and government policies like tax incentives, harmonized tax structure, infrastructural development, and financing, as well as the creation of a production hub for cotton industry and Information, Communication, and Technology (ICT) sector. Other identified objectives of the incentives are to address the problem of inputs supply, demand, and price competitiveness of Nigerian textile industry, the provision of foreign exchange requirements to direct cash grant on export performance, trade liberalization, tax relief inducements and some other industrial assistance in the form of marketing, technology advancement, packaging quality, R\&D, and innovation of Nigeria textile products, all are to improve productivity (NIRP, 2014). All these policies were designed to address these problems and encourage textile industry performance with a view of diversifying the productive base and increase its output for both domestic and export earnings. Though these programs and policies are well-intentioned and designed, they are yet to achieve the desired objectives because the industry has recently experienced a serious performance decline. For instance, the number of firms in the industry declined to about 42 in 2003, 25 in 2010 and 10 in 2011 with employment falling to 60,000 in 2002 and 24,000 in 2010 (Banjoko et al., 2012). Smuggling is also common in the industry (Uexkull and Shui, 2014). This decline in the performances of the Nigerian textile industry occurs despite various policies designed in its support. It is notable that textile is a major item on the Nigerian import prohibition list. Firms in the industry also benefit from some incentives in the forms of pioneer status and subsidies. Therefore, given the declining performance of the 
industry, there is need to evaluate the effect of trade policies such as trade liberalization on the performance of the textile industry in Nigeria.

Research Objectives: The major objective of this study is to evaluate the effect of trade liberalization on the performance of the Nigerian textiles industry. Specifically, this study is set-out to;

- Determine the effect of simple tariff rate on the exportation of textiles product in Nigeria.

- Examine the effect of the real effective exchange rate on textiles export value in Nigeria.

- Determine the effect of trade openness on textiles export in Nigeria textiles industry in Nigeria.

\section{Research Questions}

- What is the effect of simple tariff rate on the exportation of textiles product in Nigeria?

- How does the real effective exchange rate impact on textiles export value in Nigeria?

- What is the effect of trade openness on textiles export in Nigeria?

Statement of Hypothesis: The following hypotheses were formulated for assessing the effect of trade liberalization on the performance of the Nigerian textiles industry. The hypotheses were tested in this study at $5 \%$ significant level.

Ho: Simple tariff rate has a negative significant effect on the exportation of textiles product in Nigeria.

$\mathrm{H}_{1}$ : There is no significant negative effect of Simple tariff rate on the exportation of textiles product in Nigeria.

Ho: Real effective exchange rate has a significant effect on textiles export value in Nigeria.

$\mathrm{H}_{1}$ : Real effective exchange rate has no significant effect on textiles export value in Nigeria.

Ho: Trade openness has a significant effect on the Nigerian textiles industry export rate.

$\mathrm{H}_{1}$ : Trade openness has no significant effect on the Nigerian textiles industry export rate.

\section{Literature Review}

Trade liberalization is viewed in this study as a deep-rooted agreement by compliant nations for the complete removal or partial reduction of several trade restrictive instruments that hinders the free flow of goods across borders. In the literature, there are conflicting results on trade liberalization and performance; some studies claimed a positive relationship (Yahya, Dantama and Abdullahi, 2013; Kazem and Reza, 2012 and Manni and Afzal 2012), while others established a negative association between trade liberalization and performance. Specifically, the notion that trade liberalization enhances the economic growth of the developing countries is confirmed in the work of Yahya et al. (2013) in which the relationship between trade liberalization and economic growth in Sub-Saharan Africa was examined. Likewise, in the work of Kazem and Reza (2012) who carried out a study on the impact of trade liberalization on Iran's economic growth, it was discovered that trade liberalization has a positive impact on Iran's economic growth. Similarly, Frensch (2010) also found out that trade liberalization helps emerging economies to be successfully involved in import-led growth strategies, which leads to rapid economic growth. While, Thu and Lee (2015) also supported this view by revealing that trade liberalization has a strong positive impact on total output, exports, and imports in Vietnam.

Ali-Hussien, Ahmed, and Yousaf (2012) discovered that Sub-Saharan African countries that adopted the trade liberalization program have shown a substantial boost in their trade share. This discovery is confirmed in the work of Manni and Afzal (2012) who assessed the impact of trade liberalization on Bangladesh economy between 1980 and 2010 and found out that the Bangladesh Gross Domestic Product (GDP) increased significantly, after the country's adoption of trade liberalization policy. Findings of El-Wassal (2012) also attest to the fact that trade liberalization is statistically and positively correlated with the economic growth of twenty (20) Arab countries over the period of 1995 to 2010. Correspondingly, within the Nigerian context, Bakare and Fawehinmi (2011) revealed that since 1986, trade liberalization has led to sustainable impact in the country's non-oil industrial sector. In contrast to the findings in the preceding paragraph, some studies have revealed that trade liberalization has not contributed to economic growth in Nigeria (Adewuyi and Akpokodje, 2010; Olaifa et al., 2013; Oluwaleye, 2014). 
Ricardian Trade Model propounded by David Ricardo, (1772 - 1823), Ricardian theory of comparative advantage is perhaps the most important concept in international trade theory (Krugman and Obstfield, 2003). Ricardo intuition was that trade is advantageous even when a single country has an absolute advantage in the production of two goods. According to him, what matter is not an absolute advantage but comparative advantage? Ricardo model assumed two countries that consume two products and that both products are produced with labor alone. The model further assumes constant returns to scale in production, competitive firms, no role for institution and government policies among others. Therefore, the model focuses on labour productivity as the main determinant of trade. The model demonstrates that under a free trade regime, countries could trade and specialize their pattern of production in accordance with a comparative advantage while also assigning a role for wages and productivity among competitive countries of the world. Aside from these, Ricardo's trade model is very simple and some of its assumptions are unrealistic and for these reasons, the model is not able to fully capture many factors determining trade.

The Slow Growth Model: The Solow Growth Model is a model of capital accumulation in a pure production economy. The model assumes that there are no prices and everyone works all the time. The model further assumes that production technology uses labour and capital as the main input into the production process while technology is exogenous (Romer, 1999). Hence, capital accumulation is important for production the production of output. Solow growth model makes the following assumptions about the production function: The model assumes constant returns to scale, Marginal products of capital and labor are positive, but declining; both production factors are necessary and Inada conditions are satisfied.

Endogenous Growth Model: Endogenous growth theory explains long-run growth as emanating from economic activities that create new technological knowledge. This suggests that technical progress is determined by the model rather than assumed given as in the Solow Growth Model. Endogenous growth is long-run economic growth at a rate determined by forces that are internal to the economic system, particularly those forces governing the opportunities and incentives to create technological knowledge. In the long run, the rate of economic growth, as measured by the growth rate of output per person, depends on the growth rate of total factor productivity (TFP), which is determined in turn by the rate of technological progress. The neoclassical growth theory of Solow (1956) and Swan (1956) assumes the rate of technological progress to be determined by a scientific process that is separate from, and independent of, economic forces.

Trade liberalization and Performance: An empirical study carried out by Petreski (2013) to analyze the impact of CEFTA-2006 on trade, revealed that CEFTA-2006 has exerted a positive effect on trade in Southeastern Europe. Oladipo (2011) also examined the impact of trade openness on Mexico's economic growth and discovered that the long run economic growth in Mexico is largely attributed to the degree of Mexico's trade openness. El-Anis (2013) also examined the overall level of bilateral trade between Jordan and the United States before and after the Jordan-United States Free Trade Agreements (JUSFTA) came into effect and discovered that Jordan has benefitted from an overall trade surplus since the implementation of the JordanUnited States Free Trade Agreements (JUSFTA), compared to the trade deficit experienced in the pre-JordanUnited States Free Trade Agreements (JUSFTA) era. Additionally, Matthias, Steffen, and Groening (2012) assessed the impact of Jordan's substantial trade liberalization over the last two decades and found out that the Free Trade Agreement (FTA) with the United States has boosted the country's exports to a considerable degree. Equally, the findings of the study carried out by Yucel (2014) shows that, the customs union between Turkey and the European Union has strengthened the economic and commercial ties of Turkey. Andrzej and Hagemejer (2011) also evaluated the effectiveness of preferential trade liberalization in Central and Eastern Europe and discovered that all forms of preferential trade liberalization contributed significantly to the expansion of trade of the Central and Eastern Europe (CEE) countries. In addition, Bustos (2011) carried out a study on the impact of the regional trade agreement on Argentinean firms and discovered that expanded export opportunities have a positive effect on firm performance in Argentina. Also, Parinduria and Thangavelu (2013) found out that the free trade agreement between the United States and Singapore increases the value of firms in Singapore.

Conversely, a study carried out by Boyrie and John (2013) to ascertain the effect of trade openness on the growth of major Latin American economies shows that trade openness does not significantly contribute to growth, in major Latin American economies. This view is also supported by the study carried by Safuan 
(2012) who discovered that disparity of potential economic benefit exists among ASEAN member countries. Yoko et al. (2013) investigated the effect of the termination of the Multifibre Agreement (MFA) on the Cambodian garment firms and found out that the termination of the MFA did not stop the growth of the Cambodian garment industry. Dadakas and Katranidis (2010) analysed the welfare effects of the MFA and the Agreement on Textiles and Clothing (ATC) regime, on the cotton-yarn sector in Greece and found out that the openness to trade did not change the pattern of import protection in the yarn sector nor affect the magnitude of transfers to Greek yarn producers. Similarly, Sunariyo et al. (2015) analyse the impact of trade openness on the performance of palm coconut plantations in Indonesia and discovered that the trade openness has no significant impact on firm's performance, especially on domestic demand of palm coconut in Indonesia.

\section{Methodology}

Theoretical Framework: This study augmented the endogenous growth model. The endogenous growth model explains countries long-run growth as emanating from forces that are internal to a system. In the model, the main drivers of long-run growth considered are human capital, labor force, physical capital and total factor productivity. These inputs are paid their marginal products. A formal analytical framework for deriving the determinants of output performance in which trade policies such as trade liberalization is included is developed. The initial step in the process is the specification of an explicit Cobb-Douglas production function of the usual form as follow;

$Y_{t}=A_{t}\left(K_{t}^{\propto} L_{t}^{\beta}\right)$

Note: $\propto<1, \beta<1$

$A_{t}=A(0) E i^{t}$

Where $\mathrm{Y}$ is the output of textile, $\mathrm{k}$ and $\mathrm{L}$ are measures of capital and labor services employed, while $\mathrm{A}$ is the measure of total factor productivity performance. Substituting equation (2) in (1), we have;

$Y_{t}=A(0) E i^{t} K^{\alpha} L^{1-\alpha}$

Taking the growth rate of equation (3), we have;

$y=a(0) e i^{t} k^{\alpha} l^{1-\alpha}$

Where $y$ is the growth rate of textile output, $\mathrm{k}$ and $\mathrm{L}$ are the growth rates of measures of capital and labor services employed, while components of (a) are measures of the growth rate of output which are linearly associated with measures of trade policy such as trade liberalization. Equation (4) implies that trade policy, influence the efficiency of the production process. However, in order to investigate the effect of trade liberalization on the performance of textiles industry, equation (4) is transformed to the following:

$y=a(0) e i^{t} k^{\alpha} l^{1-\alpha}+e$

Where e is the random variable or white noise error term which captures the impact of other variables not included in the model. Therefore, this study incorporated other growth determinants variables such as energy required to produce the textile product, financial development, human capital, and trade openness. This is done in order to underscore whether there are different effects for incorporating these macroeconomic series in modeling the relationship between trade liberalization and performance of textiles industry in Nigeria. Equation 5 with other determinants of variables that influences the performance of textile industry can be explained by equation 6

$y=a(0) e i^{t} k^{\alpha} l^{1-\alpha}+$ Energy + openness + Find $+H c+e$

Thus, the relationship between trade liberalization and performance of textiles industry in Nigeria is examined in equation (6) with the addition of other important determinants factors. To this end, equation 6 can be converted into a linear relationship given in equation (7)

$y_{t}=\alpha_{0}+\alpha_{1}$ Energy $_{t}+\alpha_{2}$ Openness $_{t}+\alpha_{3}$ Find $_{t}+\alpha_{4} H C_{t}+\alpha_{5} K_{t}+\alpha_{6}$ Lab $_{t}+\alpha_{7} T L_{t}+$

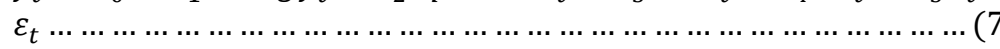

Since the main objective of this paper is to investigate the effect of trade liberalization on textile industry performance in Nigeria, there is need to decide on the measurement of trade liberalization indicators. Following the literature, this study employs the popular trade liberalization indicators that are often measured by most favored nation (MFN) simple mean (all products, \%). 
Model Specification: Based on the framework developed above, the estimable model for this study can be specified as follows ${ }^{1}$;

$$
\begin{aligned}
& y_{t}=\alpha_{0}+\alpha_{1} \text { Energy }_{t}+\alpha_{2} \text { Openness }_{t}+\alpha_{3} \text { Find }_{t}+\alpha_{4} \text { EXC }_{t}+\alpha_{5} H C_{t}+\alpha_{6} K_{t}+\alpha_{7} \text { Lab }_{t}+\alpha_{8} \text { STR }_{t}
\end{aligned}
$$

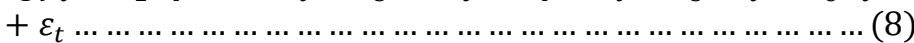

Where

$\mathrm{y}=$ output of textile industry that is proxy by textile export value

$\mathrm{K}=$ Physical Capital that is proxy by Gross fixed capital formation (\% of GDP)

$\mathrm{LAB}=$ Labour force that is represented by Population, total

Energy $=$ Energy use (kg of oil equivalent per capita)

Find $=$ Domestic credit to private sector (\% of GDP)

EXC $=$ Real effective exchange rate index $(2010=100)$

Openness $=$ Trade Openness (the ratio of total trade to GDP)

HC = Human capital that is represented by Secondary School Enrollment, (gross), gender parity index (GPI)

STR $=$ Tariff rate, most favored nation, simple mean, all products (\%)

$\varepsilon_{t}=$ White noise stochastic term

$\mathrm{t}=$ time $(1986-2015)$

Estimation Techniques: We employ a time series data and a linear autoregressive distributed lag model (ARDL). The model helps to capture both linear long and short-run impacts of trade liberalization on textile industry performance in Nigeria. The study follows Pesaran, Shin, and Smith, (2001) bound test cointegration techniques. According to Pesaran et al. (2001), the method is valid irrespective of whether the series is stationary at level or after first difference. The advantages of the techniques over other multivariate co-integration is that it is a simpler approach that permits the co-integration relationship to be estimated in a single equation specification; once the lag order of the model is identified. Therefore, equation 8is respecified in an ARDL format as:

$$
\begin{aligned}
& \Delta y_{t}=\alpha_{0}+\alpha_{1} \text { Energy }_{t-1}+\alpha_{2} \text { Openness }_{t-1}+\alpha_{3} \text { Find }_{t-1}+\alpha_{4} \text { EXC }_{t-1}+\alpha_{5} H C_{t-1}+\alpha_{6} K_{t-1}+\alpha_{7} \text { Lab }_{t-1} \\
& +\alpha_{8} S T R_{t-1}+\sum_{i=1}^{p} \alpha_{i} \Delta \text { Energy }_{t-i}+\sum_{i=1}^{p} \alpha_{i} \Delta \text { Openness }_{t-i}+\sum_{i=1}^{p} \alpha_{i} \Delta \text { Find }_{t-i}+\sum_{i=1}^{p} \alpha_{i} \Delta H C_{t-i} \\
& +\sum_{i=1}^{p} \alpha_{i} \Delta K_{t-i}+\sum_{i=1}^{p} \alpha_{i} \Delta L a b_{t-i}+\sum_{i=1}^{p} \alpha_{i} \Delta S T R_{t-i}
\end{aligned}
$$

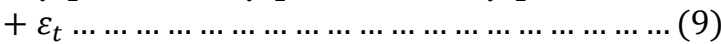

All variables are defined before. According to Pesaran et al. (2001), the decision rule for determining the level relationship or otherwise co-integration is that computed F-statistic must be greater than the critical lower I (0) and upper I (1) bound value, otherwise, there is no level relationship. However, if the calculated Fstatistics falls within the band, then the inference is inconclusive.

\section{Variable definition and Measurement}

Trade Openness: This is the most natural measure of a country's integration in world trade (WTO, 2012). Trade Openness is measured as the sum of imports and exports over a country's Gross Domestic Product (GDP).

Real Effective Exchange Rate (REER): The real effective exchange rate is a measure of the domestic economy's price competitiveness in comparison with its trading partners (WTO, 2012). The calculation of Nigeria's REER calculations is retrieved from the world development indication, 2017 online version from 1986 to 2015.

Textiles Industry performance: is the value of Nigeria's textiles exports to the rest of the world over a period of time. The aggregate export data on textiles products is available at the World Integrated Trade Solution from 1986 to 2015. This data set was used to measure textiles industry performance rate in this study.

\footnotetext{
${ }^{1}$ Incorporating these two measures of trade liberalization into equation 7 yield 8 and 9;
} 
Trade Liberalization that is proxy by Simple Tariff Rate; the indicator is defined as the simple average tariff imposed on all exports from developing countries and LDCs. The Simple average tariff is the unweight average of the effectively applied rates for all products. The data set is freely available at the World Development Indicator, 2017 database. This study uses the simple tariff rate, most favored nation ${ }^{2}$, simple mean, all products (\%).

\section{Results and Discussion of Findings}

The results in this study follow three (3) steps; pre-estimation, estimation and post estimation analysis. All these were done in other to validate the stability of the study.

Table 1: Descriptive Statistics for variables in the model

\begin{tabular}{llllllllll}
\hline & ENERGY & EXC & FIND & HC & K & LAB & STR & TRADE & Y \\
\hline Mean & 6.579 & 4.599 & 2.630 & -0.211 & 2.347 & 18.640 & 3.048 & 0.542 & 9.709 \\
Median & 6.576 & 4.506 & 2.577 & -0.233 & 2.438 & 18.639 & 3.195 & 0.579 & 9.321 \\
Maximum & 6.680 & 5.607 & 3.648 & -0.088 & 2.807 & 18.994 & 4.306 & 0.818 & 12.981 \\
Minimum & 6.506 & 3.907 & 2.164 & -0.324 & 1.697 & 18.271 & 2.415 & 0.214 & 5.620 \\
Std. Dev. & 0.050 & 0.439 & 0.341 & 0.049 & 0.321 & 0.222 & 0.526 & 0.154 & 2.098 \\
Skewness & 0.242 & 0.945 & 1.475 & 0.314 & -0.242 & -0.021 & 0.185 & -0.446 & -0.127 \\
Kurtosis & 1.869 & 3.276 & 5.293 & 3.107 & 1.680 & 1.771 & 2.047 & 2.527 & 1.870 \\
Jarque-Bera & 1.890 & 4.564 & 17.452 & 0.508 & 2.470 & 1.889 & 1.308 & 1.275 & 1.677 \\
Probability & 0.389 & 0.102 & 0.000 & 0.776 & 0.291 & 0.389 & 0.520 & 0.529 & 0.432 \\
Sum & 197.380 & 137.957 & 78.894 & -6.325 & 70.407 & 559.200 & 91.434 & 16.268 & 291.276 \\
Sum Sq. Dev. & 0.072 & 5.586 & 3.363 & 0.069 & 2.983 & 1.427 & 8.034 & 0.690 & 127.661 \\
Observations & 30 & 30 & 30 & 30 & 30 & 30 & 30 & 30 & 30 \\
\hline
\end{tabular}

Table 2: Correlation Analysis of the Variables used in the Regression Analysis

\begin{tabular}{llllllllll}
\hline & ENERGY & EXC & FIND & HC & K & LAB & STR & TRADE & Y \\
\hline ENERGY & 1.000 & & & & & & & & \\
EXC & -0.161 & 1.000 & & & & & & & \\
FIND & 0.183 & 0.008 & 1.000 & & & & & & \\
HC & 0.485 & -0.251 & 0.287 & 1.000 & & & & & \\
K & 0.187 & -0.034 & 0.016 & -0.127 & 1.000 & & & & \\
LAB & 0.889 & 0.051 & 0.340 & 0.660 & 0.028 & 1.000 & & & \\
STR & -0.826 & -0.107 & -0.360 & -0.554 & 0.000 & -0.872 & 1.000 & & \\
TRADE & -0.158 & -0.222 & 0.003 & 0.010 & -0.568 & -0.110 & 0.136 & 1.000 & \\
Y & 0.713 & -0.069 & 0.389 & 0.291 & 0.431 & 0.654 & -0.707 & -0.386 & 1.000 \\
\hline Sour
\end{tabular}

Source: Researcher's Computation (2017)

Pre-estimation Results: Descriptive Statistics and correlation Analysis: Results of the descriptive analysis of the variables used in the regression analysis are reported in Table 1. In the Table, the mean variability is higher for Labour (LAB), textile performance value (Y), and energy consumption (ENER), than real effective exchange rate (EXC), Gross fixed capital formation (K), domestic credit to private sector (Find), Secondary school enrolment (HC), simple mean tariff rate (STR) and Openness (Openness). Similarly, the pairwise correlation coefficients for the variables used is presented in Table 2. The outcomes of the correlation result are important for establishing the level of association among the variables used in the regression analysis and to determine whether the series can be included together in a single equation model. For our case, the results show a moderate coefficient and all series can co-exist in the same model.

${ }^{2}$ Most-Favored Nation Tariffs (MFN) tariffs are what countries promise to impose on imports from other members of the WTO, unless the country is part of a preferential trade agreement (such as a free trade area or customs union). 
Stationarity Test (Unit root): Further on the pre-estimation analysis, this study further examine the Stationarity properties of the data used. Although, not often required in ARDL, this study employed both Augmented Dickey-Fuller (ADF) test and Phillips-Perron standard unit root test. The results of the unit root tests are summarized and presented in Table 3. Test for Stationarity shows that all the series are stationary after first difference except for real effective exchange rate, human capital development, and trade openness that are integrated of order I(0) and thus, stationary at levels.

Table 3: Unit Root Tests Results

\begin{tabular}{|c|c|c|c|c|}
\hline \multirow[t]{2}{*}{ Variable } & & \multicolumn{3}{|c|}{ Unit Root Tests } \\
\hline & & ADF & PP & Decision \\
\hline \multirow[t]{2}{*}{ Energy } & Level & -1.2201 & -0.9797 & $\mathrm{I}(1)$ \\
\hline & 1st Difference & $-4.9725^{*}$ & $-8.8299 *$ & \\
\hline \multirow[t]{2}{*}{ EXC } & Level & $-3.2211^{* *}$ & $-3.4189^{* *}$ & $\mathrm{I}(0)$ \\
\hline & $1^{\text {st }}$ Difference & $-5.6671^{*}$ & $-5.6977^{*}$ & \\
\hline \multirow[t]{2}{*}{ FIND } & Level & -2.5030 & -2.4966 & $\mathrm{I}(1)$ \\
\hline & $1^{\text {st }}$ Difference & $-4.8749 *$ & $-7.5451^{*}$ & \\
\hline \multirow[t]{2}{*}{$\mathrm{HC}$} & Level & $-3.6037^{*}$ & $-3.5849^{*}$ & $\mathrm{I}(0)$ \\
\hline & $1^{\text {st }}$ Difference & $-6.7620^{*}$ & -13.8999* & \\
\hline \multirow[t]{2}{*}{ K } & Level & -1.7476 & -1.6897 & $\mathrm{I}(1)$ \\
\hline & $1^{\text {st }}$ Difference & $-5.4995^{*}$ & $-5.1404^{*}$ & \\
\hline \multirow[t]{2}{*}{ LAB } & Level & -1.0262 & -1.5221 & $\mathrm{I}(1)$ \\
\hline & $1^{\text {st }}$ Difference & $-3.5461^{* *}$ & $-4.0384^{* *}$ & \\
\hline \multirow[t]{2}{*}{ STR } & Level & -1.3572 & -1.1011 & $\mathrm{I}(1)$ \\
\hline & $1^{\text {st }}$ Difference & $-7.0235^{*}$ & $-8.5782 *$ & \\
\hline \multirow[t]{2}{*}{ OPENNESS } & Level & $-3.6059 * *$ & $-3.6129 * *$ & $\mathrm{I}(0)$ \\
\hline & $1^{\text {st }}$ Difference & $-5.2195^{*}$ & $-8.2587^{*}$ & \\
\hline \multirow[t]{2}{*}{ Y } & Level & -1.6643 & -1.5612 & $\mathrm{I}(1)$ \\
\hline & $1^{\text {st }}$ Difference & $-7.6424 *$ & $-7.6876^{*}$ & \\
\hline
\end{tabular}

Note: ${ }^{*}{ }^{* *}$ and ${ }^{* * *}$ denote $1 \%, 5 \%$ and $10 \%$ significance level respectively, the optimal lag structure is determined by SIC. Source: Researcher's Estimation (2017)

Empirical Estimate of the model- Objective 1: Effect of Simple Tariff rate on Performance of Textile Industry- Proceeding to the co-integration test for objective 1; the bounds co-integration test result revealed that the computed F-Statistics for Wald test is 4.59 on approximation and the value exceeds both the upper bounds and lower bounds critical values for all level of significance (see Table 4). Therefore, there is a longrun relationship between simple tariff rates, financial development, energy consumption, openness and textile industry performance in Nigeria.

Table 4: Bounds Testing for Co-Integration Analysis

\begin{tabular}{lll}
\hline Computed Wald F-Statistic: & 4.5912 (AIC Lags $=\mathbf{~ 1 )}$ & \\
\hline Bounds level: & Lower I(0): & Upper I(1): \\
$1 \%$ critical bounds value & 2.79 & 4.10 \\
$5 \%$ critical bounds value & 2.22 & 3.39 \\
$10 \%$ critical bounds value & 1.95 & 3.06 \\
\hline
\end{tabular}

Source: Researcher's computation using E-views, 10

After establishing long-run relationship on the objective, we further estimated the impact of simple tariff rate on performance of the textile industry in Nigeria ${ }^{3}$. The outcomes of the objective are presented in Table 5. In the long-run, simple tariff rate is negative and significantly related to on textile industry performance in Nigeria. This implies that a $1.0 \%$ rise in simple tariff rate would decrease the level of the textile industry performance by $5.96 \%$ on approximation.

${ }^{3}$ All variables were logged and estimation period is from 1986-2015. 


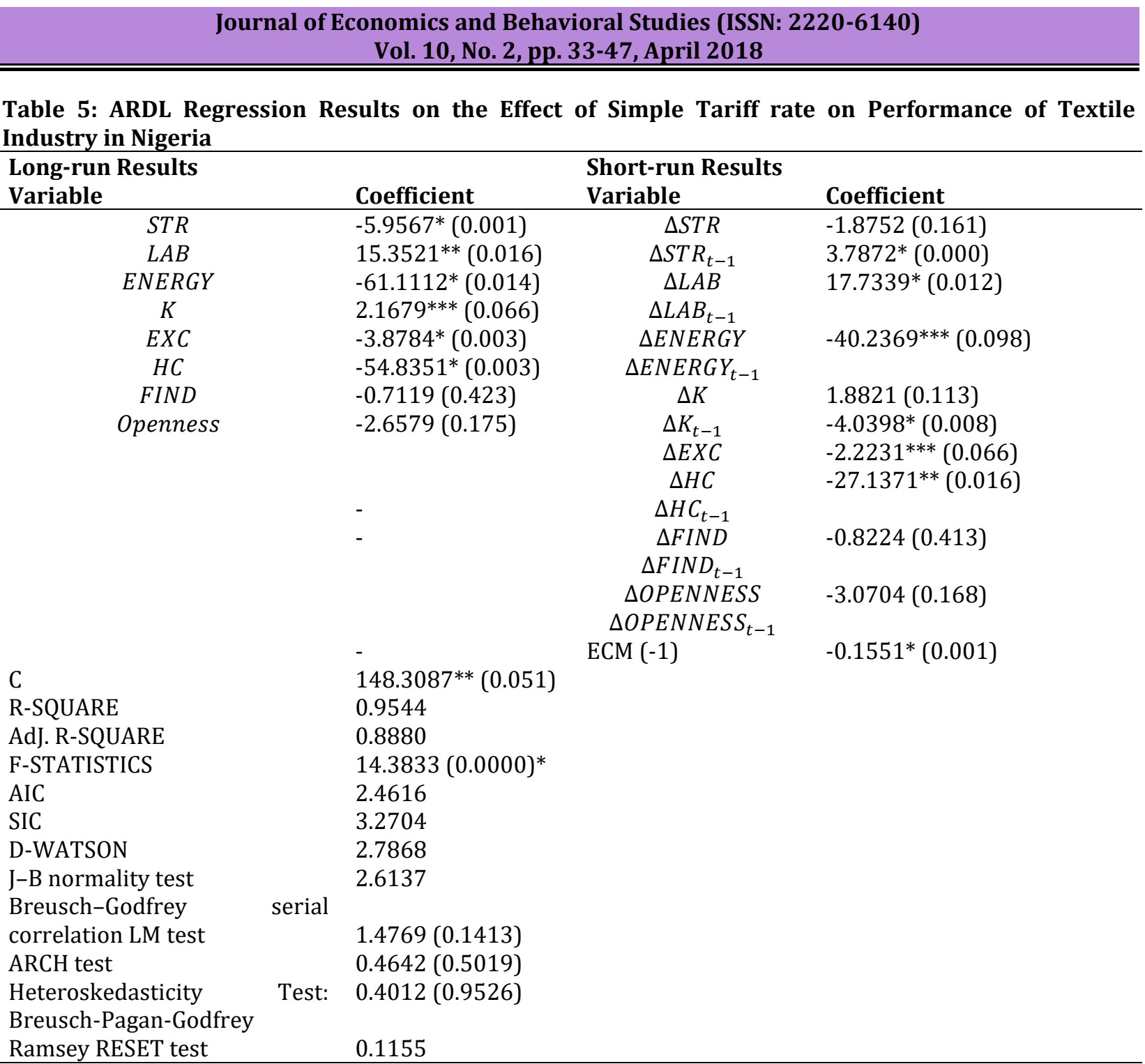

Note: ${ }^{*}, * *$ and ${ }^{* * *}$ denote $1 \%, 5 \%$ and $10 \%$ significance level respectively and probability values in parenthesis. Source: Researcher's Estimation from E-views, 10

Also, a $1.0 \%$ rise in both capital and labour input use lead to about $2.17 \%$ and $15.35 \%$ increase in textile industry performance, while energy consumption dampens the industry performance by about $61.11 \%$. The effect of exchange rate is negative and significant on textile industry performance in Nigeria, while human capital development, trade openness and financial development are negatively related with the textile industry performance. However, in the short-run, evidence shows that trade liberalization policy measure through simple tariff rate has a lag effect before it can be effective in the textile industry in Nigeria. The results, however, show a positive significant lagged effect for simple tariff rate impact on textile industry performance in Nigeria. Specifically, a $1.0 \%$ rise in past simple tariff rate value (trade policy) raises the level of textile growth by about $3.78 \%$, while the current increases in tariff rate lower the textile industry performance by $1.88 \%$ over the period of analysis. In general, the major factor affecting the textile industry performances in short-run are simple tariff rate, labour force, energy inputs, exchange rate fluctuations and human capital development in Nigeria. Moreover, the speed of adjustment to restore equilibrium in the dynamic model following a disturbance is around -0.155 , implying that a deviation from the long-run equilibrium is corrected for by approximately $15 \%$ after each year. In addition to the above results, the CUSUM and CUSUM square parameter stability test was conducted and presented in figure 1 and 2 to show that the estimated parameters in this study is stable during the sample period (1986-2015). 
This study concurs with the Solow growth theory which argues that production technology uses labour and capital as the main input into the production process while energy consumption decreases it's because of additional costs which are paid out of profits. It also validates the null hypothesis which assumed that simple tariff rate has a negative significant effect on the exportation of textiles product in Nigeria. Consequently, one may hypothesize a positive relationship between simple tariff rate (STR) and textile industry performance because of industrial protection across the industries. Such a relationship may however, not hold in the Nigerian case because the government over the years has been opening up the boarder to encourage imports. The results from this study concurs with the views of Ahmed (2016) and Musila and Yiheyis, 2015 who argues that both exchange rate devaluation that is associated with free trade policy will allow the prices of imported intermediate inputs to rise which will then impact negatively on output growth.

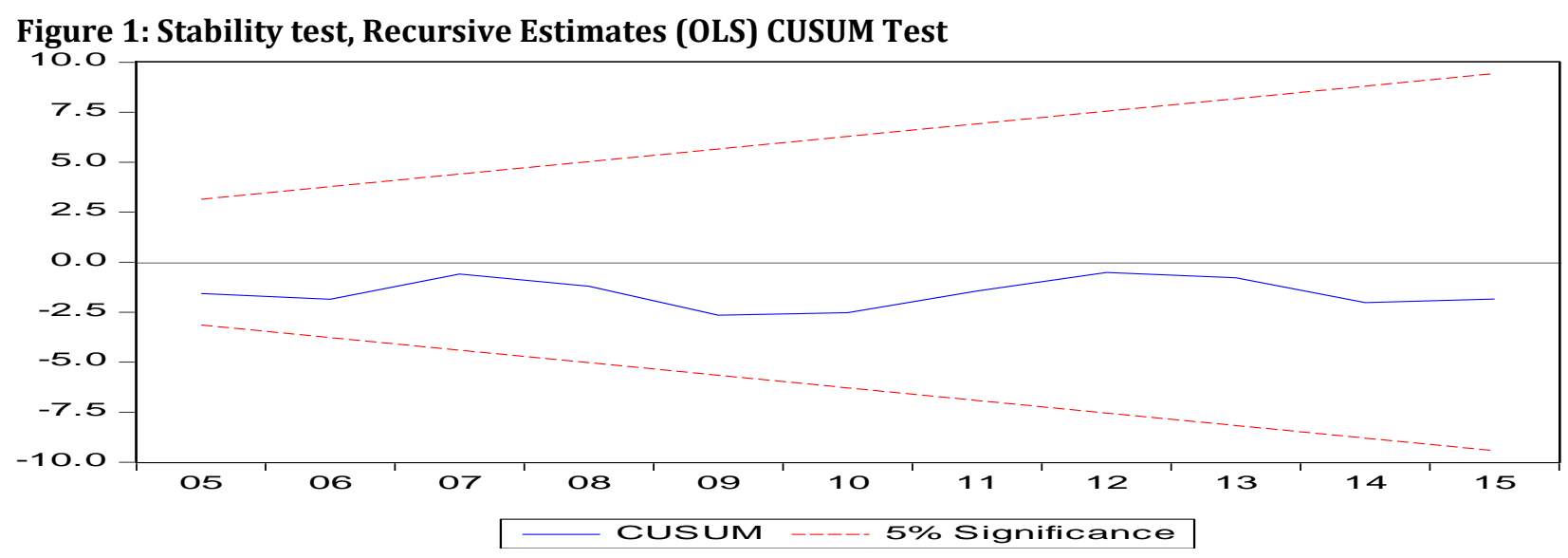

Figure 2: Stability test, Recursive Estimates (OLS) CUSUM of Squares Test

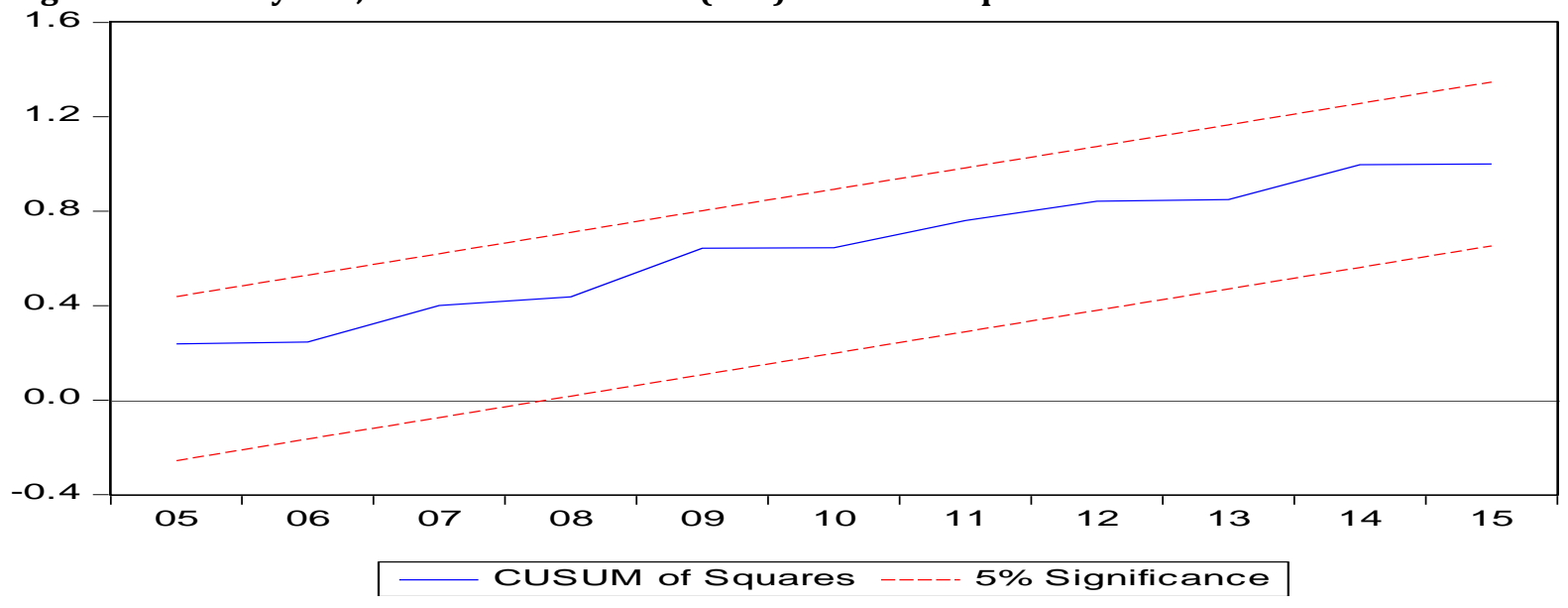

In general, the overall fit of the analysis is quite good ( $R 2=0.95$ and adjusted $\mathrm{R} 2=0.89$ ) as explained by the $\mathrm{R}$-squared. The R-squared shows that our model explained approximately $95 \%$ variations in textile performance in Nigeria without autocorrelation as shown in the value of Durbin-Watson test statistics. Thus, shows that the result is reliable in explaining the dynamic between textiles industry performance and trade liberalization in Nigeria.

Effect of the Nigerian Real Effective Exchange Rate on Textiles Industry Performance: For objective 2; the bounds test statistic yields evidence of a long-run relationship between our measure of exchange rate and textile industry performance in Nigeria. 
Table 6: Bounds Testing for Co-Integration Analysis

\begin{tabular}{lll}
\hline Computed Wald F-Statistic: & $\mathbf{4 . 9 8 0 8}$ (AIC Lags $\mathbf{~ 1 ) ~}$ & \\
\hline Bounds level: & Lower I(0): & Upper I(1): \\
1\% critical bounds value & 3.15 & 4.43 \\
$5 \%$ critical bounds value & 2.45 & 3.61 \\
$10 \%$ critical bounds value & 2.12 & 3.23
\end{tabular}

Notes: for the Wald F-Statistic; Asymptotic critical value bounds are obtained from Table C1 (iii) Case III: unrestricted intercept and no trend for $k=6$ (Pesaran et al., 2001, pg. 300).

Source: Researcher's computation, (2017)

Table 7: ARDL Regression Results on the effect of Real Effective Exchange Rate on Textile Industry in Nigeria

\begin{tabular}{|c|c|c|c|}
\hline \multicolumn{2}{|l|}{ Long-run Results } & \multicolumn{2}{|l|}{ Short-run Results } \\
\hline Variable & Coefficient & Variable & Coefficient \\
\hline$L A B$ & $11.6459^{*}(0.012)$ & $\Delta S T R_{t-1}$ & \\
\hline ENERGY & $-10.1432(0.517)$ & $\triangle L A B$ & $-0.2478(0.987)$ \\
\hline$K$ & $2.1679^{* * *}(0.066)$ & $\Delta L A B_{t-1}$ & $2574.2902 *(0.003)$ \\
\hline$E X C$ & $-1.6026^{* *}(0.025)$ & $\triangle E N E R G Y$ & $-10.9632(0.462)$ \\
\hline$H C$ & $-39.3469 *(0.001)$ & $\Delta E N E R G Y_{t-1}$ & $-17.7695(0.161)$ \\
\hline FIND & & $\Delta K$ & $0.5917(0.558)$ \\
\hline \multirow[t]{7}{*}{ Openness } & $2.3049(0.157)$ & $\Delta K_{t-1}$ & $-4.0398 *(0.008)$ \\
\hline & & $\triangle E X C$ & $-0.2064(0.838)$ \\
\hline & & $\Delta H C$ & $-12.2937(0.153)$ \\
\hline & - & $\Delta H C_{t-1}$ & $18.7949^{* *}(0.029)$ \\
\hline & - & $\triangle F I N D$ & $-0.8224(0.413)$ \\
\hline & & $\triangle O P E N N E S S$ & $3.2197(0.155)$ \\
\hline & - & $\operatorname{ECM}(-1)$ & $-0.3969 *(0.000)$ \\
\hline $\mathrm{C}$ & $-191.3564 *(0.000)$ & & \\
\hline R-SQUARE & 0.9095 & & \\
\hline AdJ. R-SQUARE & 0.8121 & & \\
\hline F-STATISTICS & $9.3341(0.0001)^{*}$ & & \\
\hline AIC & 3.0035 & & \\
\hline SIC & 3.7172 & & \\
\hline D-WATSON & 2.2721 & & \\
\hline J-B normality test & 1.2720 & & \\
\hline $\begin{array}{l}\text { Breusch-Godfrey } \\
\text { serial correlation }\end{array}$ & & & \\
\hline LM test & $0.7238(0.4116)$ & & \\
\hline ARCH test & $0.3159(0.9775)$ & & \\
\hline Heteroskedasticity & $0.87076(0.3597)$ & & \\
\hline Test: $\quad$ Breusch- & & & \\
\hline Pagan-Godfrey & & & \\
\hline Ramsey RESET test & $2.7339(0.1241)$ & & \\
\hline
\end{tabular}

Note: ${ }^{*}, * *$ and ${ }^{* * *}$ denote $1 \%, 5 \%$ and $10 \%$ significance level respectively and probability values in parenthesis. Source: Estimated from E-views, 10

The empirical analysis of the effect of real effective exchange rate on textile industry performance in Nigeria showed that in both long and short-run, exchange rate impact negatively on the textile industry performance in Nigeria. This implies that a $1.0 \%$ appreciation in the real effective exchange rate would decrease the level of textile performance by about $1.60 \%$. This finding concur with the study of Arezki et al. (2012), who claimed that commodity exporting countries face larger terms of trade fluctuations which render their real exchange rate volatile than other countries. They reiterated further that increased volatility in the real effective exchange rate hurts the economy through its adverse consequences on private agents' consumption and investment decisions. Also, the result further showed that a $1.0 \%$ rise in trade openness will help mitigates the performance of the textile industry in Nigeria in both long and short-run. This result is in line with the 
work of Yanikkaya, (2003), who emphasized that trade openness enhances economic growth through increased variety of intermediate goods and capital equipment, access to more efficient technology, and higher capacity utilization. Equally, trade openness provides larger market for domestic producers and allows them to reap the benefits of international trade (Alam et al., 2012; Falvey et al., 2013).

\section{Figure 3: Stability test, Recursive Estimates (OLS) CUSUM Test}

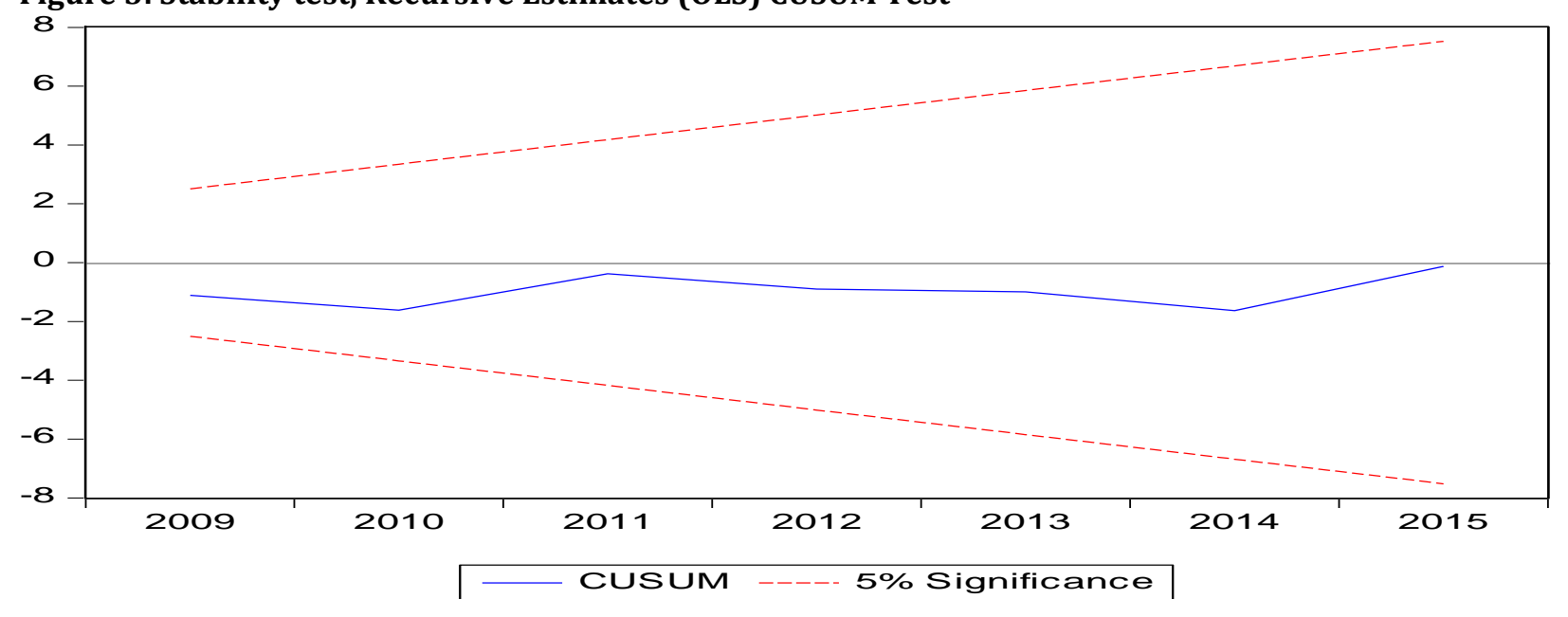

Figure 4: Stability test, Recursive Estimates (OLS) CUSUM of Squares Test

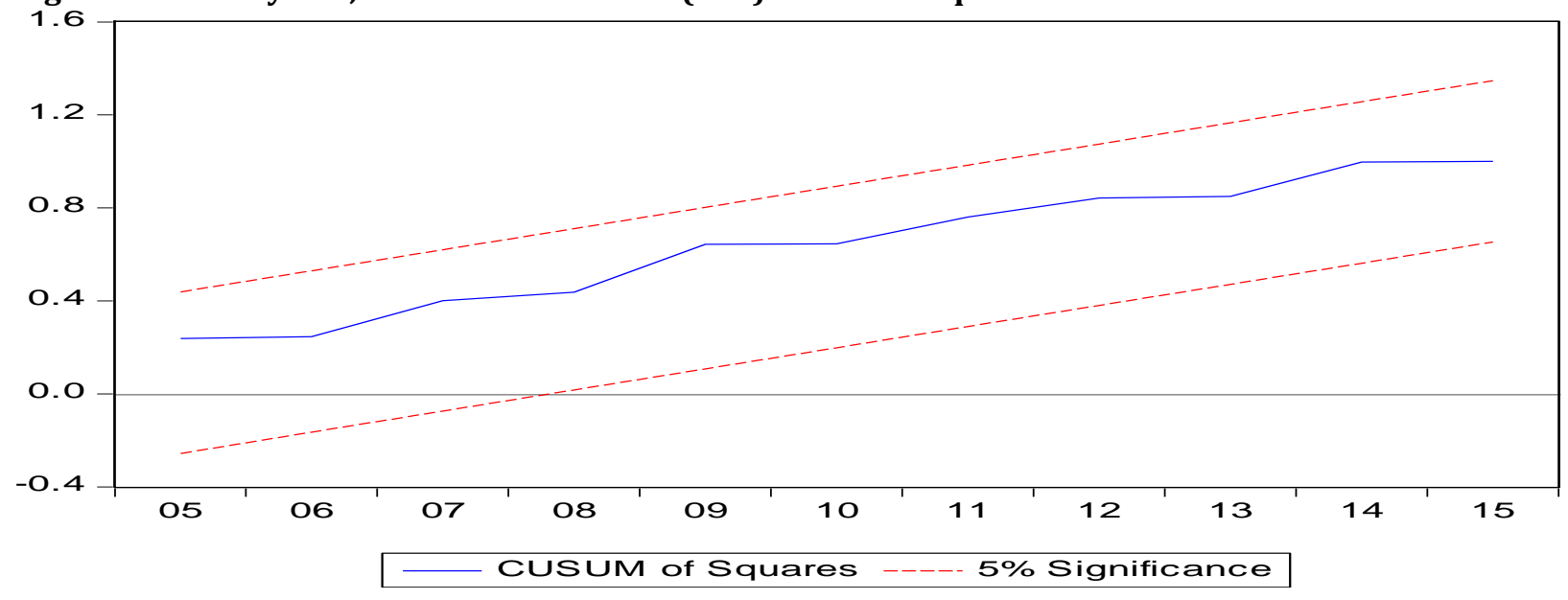

Effect of trade openness on textiles industry Performance in Nigeria: The empirical analysis of objective 3 is carried out in Table 8 and 9 respectively. Starting from the bounds test co-integration, the result revealed a Wald test statistic value of 10.66 on approximation. The value is greater than both the upper bounds and lower bounds critical values according to Pesaran et al. (2001). Therefore, we concluded that there is a longrun relationship between trade openness and textile industry performance in Nigeria.

Table 8: Bounds Testing for Co-Integration Analysis

\begin{tabular}{lll}
\hline \multicolumn{2}{l}{ Computed Wald F-Statistic: } & $\mathbf{1 0 . 6 6 4 2}$ (AIC Lags $\mathbf{~ 1 )}$ \\
\hline Bounds level: & Lower I(0): & Upper I(1): \\
$1 \%$ critical bounds value & 2.79 & 4.10 \\
$5 \%$ critical bounds value & 2.22 & 3.39 \\
$10 \%$ critical bounds value & 1.95 & 3.06
\end{tabular}

Notes: for the Wald F-Statistic; Asymptotic critical value bounds are obtained from Table C1 (iii) Case III: unrestricted intercept and no trend for $k=8$ (Pesaran et al., 2001, pg. 300).

Source: Researcher's computation (2017) 
However, to determine the magnitude of the relationship between trade openness and textile industry performance in Nigeria, we proceed to estimating the ARDL and presented the results in Table 4.9below. The dependent variable is the logarithms of textile performance values.

Table 9: ARDL Regression Results on the effect of trade openness on textiles industry Performance in Nigeria

\begin{tabular}{|c|c|c|c|}
\hline Long-run Results & & Short-run Resul & \\
\hline Variable & Coefficient & Variable & Coefficient \\
\hline STR & $-2.7318(0.299)$ & $\Delta S T R$ & $-16.3248 *(0.006)$ \\
\hline$L A B$ & $-0.6845(0.879)$ & $\Delta S T R_{t-1}$ & $6.5681^{* * *}(0.059)$ \\
\hline ENERGY & $-19.3306^{*}$ & $\triangle L A B$ & \\
\hline & $(0.549)$ & & $62.0364^{* *}(0.026)$ \\
\hline$K$ & 2.7649 (0.199) & $\Delta L A B_{t-1}$ & $-20.0829 * * *(0.090)$ \\
\hline$E X C$ & $-1.8382(0.231)$ & $\triangle E N E R G Y$ & $44.5355^{* *}(0.038)$ \\
\hline$H C$ & $-54.8351^{*}$ & $\Delta E N E R G Y_{t-1}$ & \\
\hline & $(0.003)$ & & $12.5405(0.299)$ \\
\hline FIND & $3.2903^{* *}(0.018)$ & $\Delta K$ & $4.5199 * *(0.032)$ \\
\hline Openness & $-17.4957^{* *}$ & $\Delta K_{t-1}$ & \\
\hline & $(0.023)$ & & $-4.0306(0.111)$ \\
\hline & & $\triangle E X C$ & $0.3701(0.482)$ \\
\hline & & $\Delta E X C_{t-1}$ & $2.7215^{* *}(0.029)$ \\
\hline & - & $\triangle F I N D$ & $5.2999 * *(0.012)$ \\
\hline & & $\triangle O P E N N E S S$ & $-10.3996^{* *}(0.041)$ \\
\hline & & $\triangle O P E N N E S S_{t-1}$ & $2.8819(0.277)$ \\
\hline & - & ECM $(-1)$ & $-0.4819 *(0.011)$ \\
\hline $\mathrm{C}$ & $210.9124(0.249)$ & & \\
\hline R-SQUARE & 0.9959 & & \\
\hline AdJ. R-SQUARE & 0.9631 & & \\
\hline F-STATISTICS & $30.3392(0.0083)^{*}$ & & \\
\hline AIC & 0.6245 & & \\
\hline SIC & 1.8139 & & \\
\hline D-WATSON & 2.8488 & & \\
\hline J-B normality test & 2.6982 & & \\
\hline Breusch-Godfrey serial correlation & & & \\
\hline LM test & 0.1731 (0.9977) & & \\
\hline ARCH test & 0.07845 (0.7817) & & \\
\hline $\begin{array}{l}\text { Heteroskedasticity Test: Breusch- } \\
\text { Pagan-Godfrey }\end{array}$ & $0.4012(0.9526)$ & & \\
\hline Ramsey RESET test & 0.1155 & & \\
\hline
\end{tabular}

Note: ${ }^{*}, * *$ and ${ }^{* * *}$ denote $1 \%, 5 \%$ and $10 \%$ significance level respectively and probability values in parenthesis. Source: Estimated from E-views, 10

The long-run results reveal that the effect of trade openness on textile industry is negative and statistically significant at 5\%; meaning that a $1.0 \%$ rise in trade openness would decrease the level of textile industry performance by about $17.49 \%$. These findings are similar to the work of Ahmed (2016); Musila and Yiheyis, 2015; Ulaşan, 2015; Clemens and Williamson, 2001; O'Rourke, 2000, but differs with the work of Keho (2017), who found a positive relationship between trade openness and output growth in Cote d'Ivoire in both short and long run. Similar to our study, Ahmed (2016), used linear ARDL and focused on Nigeria, found a negative long-run impact of trade openness on output growth but a positive growth effect in the short run. Musila and Yiheyis, (2015) found trade-policy induced openness to have negative and significantly affected investment and the rate of economic growth in Kenya. Thus, this study proposed a restrictive trade policy on textiles materials in the country, because opening up the boarder to foreign competition has led to collapse and closure of many textile factories in Nigeria as they could not compete with the relatively cheap imports. 

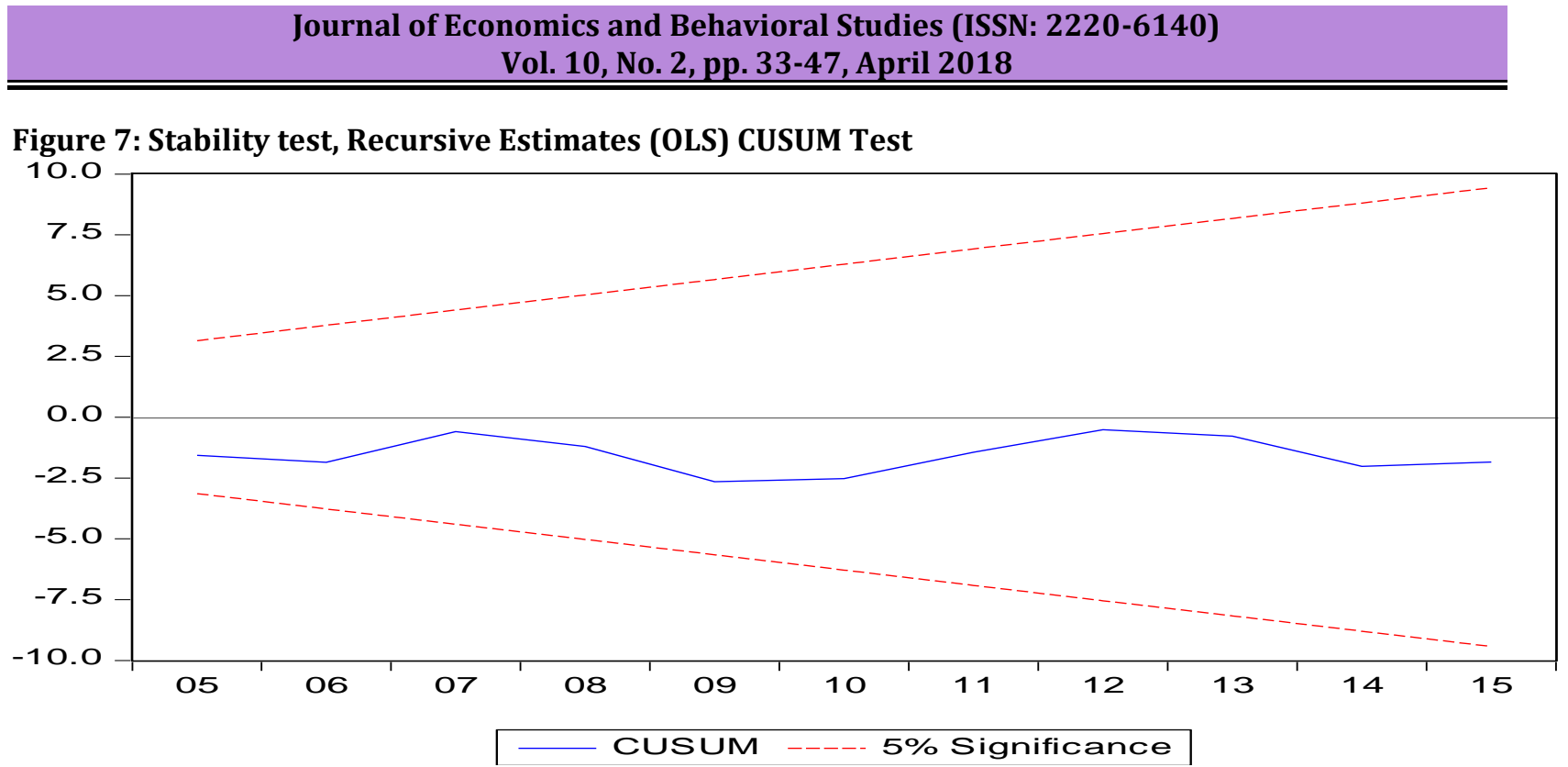

Figure 8: Stability test, Recursive Estimates (OLS) CUSUM of Squares Test

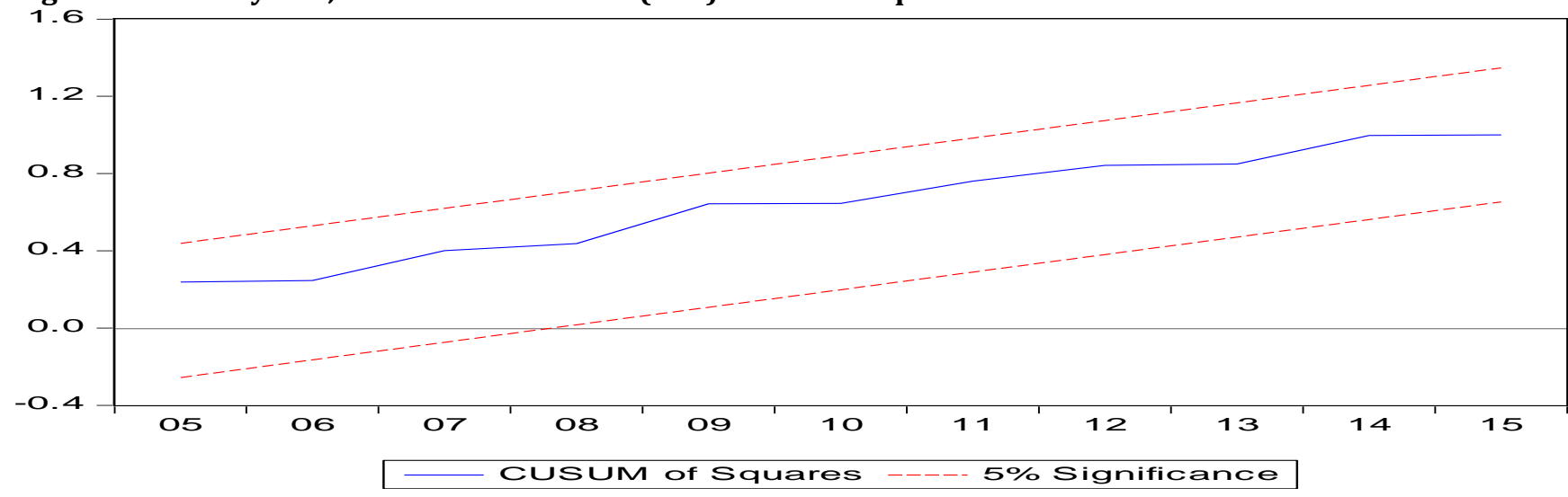

The post estimation stability test results in Figure $4.7 \& 4.8$ and Table 4.11 showed that the residual series are normally distributed as suggested by the Jarque-Bera statistics. The Breusch-Godfrey LM test statistics indicate that the model does not have significant serial correlation problem, while the ARCH test and the Ramsey RESET test respectively indicated that the residuals are homoscedastic and the model has correct functional form.

\section{Conclusion and Policy Recommendations}

This study conducted an empirical study on the relationship between trade liberalization policies and textile industry performance in Nigeria over the period 1986 -2015. The study showed that trade liberalization measured through simple tariff had a significant impact on textile industry performance in Nigeria. Trade liberalization has a lag effect on textile industry performance. Moreover, the study finds statistical significant evidence to suggest that Nigerian textile industry has benefitted from the rising appreciation in exchange rate. Hence, based on the findings of the study, we conclude that trade liberalization has significant effect on the performance of the Nigerian textile industry from 1986 to 2015. Thus, we recommend that Nigerian government should provide a favorable business environment for textile industry to strive, while putting in place right measures to curb the devaluation of the naira, in order to improve trade balance. Further, a restrictive trade policy on textiles materials in the country is require, because opening up the boarder to foreign competition will continue to expose them leading to collapse and closure of many textile factories in Nigeria as they could not compete with the relatively cheap imports. 


\section{References}

Adewuyi, A. \& Akpokodje, G. (2010). Impact of trade reform on Nigeria's trade flows. The International Trade Journal, 24(4), 411-439.

Alam, M., Buysse, J., McKenzie, A., Begum. I., Wailesc, E. \& Guido, V. (2012). The dynamic relationships between world and domestic prices of rice under the regime of agricultural trade liberalization in Bangladesh. Journal of the Asia Pacific Economy, 17(1), 113-126.

Ali Hussien, A., Ahmed, S. \& Yousaf, M. (2012). The Impact of Trade Liberalization on Trade Share and Per Capita GDP: Evidence from Sub Saharan Africa. International Journal of Economic Resources, 3(3), 44 51

Andrzej, C. \& Hagemejer, J. (2011). The effectiveness of preferential trade liberalization in Central and Eastern Europe. The International Trade Journal, 25(5), 516-531.

Arezki, R., Dumitrescu, E., Freytag, A. \& Quintyn, M. (2012). Commodity prices and exchange rate volatility: Lessons from South Africa's capital account liberalization. International Monetary Fund Working Paper, 12(168), 1-18.

Bakare, A. S. \& Fawehinmi, F. O. (2011). Trade Openness and its impact On Nigeria's Non-Oil Industrial Sector: 1979-2009. Economics and finance Review,1(5), 57 - 65.

Banjoko, S., Iwuji, I. \& Bagshaw, K. (2012). The performance of the Nigerian manufacturing sector: A 52 -year analysis of growth and retrogression (1960-2012). Journal of Asian Business Strategy, 2(8), 177-191.

Bello, O., Inyinbor, A., Dada, A. \& Oluyori, A. (2013). Impact of Nigerian Textile Industry on Economy and Environment: A Review. International Journal of Basic and Applied Sciences, 13(1), 38-103.

Boyrie, M. \& John, R. (2013). The effects of trade agreements on the growth of major Latin American economies. The Journal of International Trade and Economic Development, 22(3), 377-397.

Bustos, P. (2011). Trade liberalization, exports, and technology upgrading: Evidence on the impact of Mercosur on Argentinian firms. The American Economic Review, 101(1), 304-340.

Clemens, M. A. \& Williamson, J. G. (2001). A tariff-growth paradox; Protection's impact the world around 1875-1997, NBER working paper no. 8459. Cambridge, MA: NBER

Dadakas, D. \& Katranidis, S. (2010). The effects of trade liberalization in textiles and clothing on the Greek market for cotton yarn: A multi-market analysis. Review of international economics, 18(1), 138-152.

El-Anis, I. (2013). A review of trade liberalization and trade between Jordan and the United States. International Journal of Peace and Development Studies, 4(6), 116-124.

El-Wassal, K. A. (2012). The Impact of Trade Liberalization on Trade Balance in Arab Countries. Journal of Economic and Social Research, 14(2), 1-26.

Eneji, M., Onyinye, I., Kennedy, D. \& Rong, S. (2012). Impact of foreign trade and investment on Nigeria's textile industry: The case of China. Journal of African Studies and Development, 4(5), 130-141.

Engle, R. F. \& Granger, C. W. J. (1987). Cointegration and error correction: Representation, estimation and testing. Econometrica, 55, 251-276.

Falvey, R., Foster-McGregor, N. \& Khalid, A. (2013). Trade liberalization and growth: a threshold exploration. Journal of the Asia Pacific Economy, 18(2).

Frensch, R. (2010). Trade Liberalization and Import Margins. Emerging Markets Finance and Trade, 46(3), 422.

Johansen, S. \& Juselius, K. (1990). Maximum Likelihood Estimation and Inference on Co-integration-with Application to the Demand for Money. Oxford Bulletin of Economics and Statistics, 52(2), 169-210

Kazem, Y. \& Reza, M. (2012). Trade liberalization and economic growth: A case study of Iran. Journal of Economic Policy Reform, 15(1), 13-23.

Keho, Y. (2017). The impact of trade openness on economic growth: The case of Cote d'Ivoire. Cogent Economics \& Finance, 5, 1332820.

Krugman, P. R. \& Obstfeld, M. (2003). International Economics; Theory and Policy; Sixth Edition, Published by Pearson Education U.S

Maiwada, S. \& Renne, E. (2013). The Kaduna textile industry and the decline of textile manufacturing in Northern Nigeria, 1955-2010. Textile History, 44(2), 171-196.

Manni, U. \& Afzal, M. (2012). Effect of trade liberalization on economic growth of developing countries: A case of Bangladesh economy. Journal of Business, Economics and Finance, 1(2), 37- 44.

Matthias, B., Steffen, G. \& Groening, S. (2012). Assessing the impact of trade liberalization: The case of Jordan. Journal of Economic Integration, 27(3), 466-486. 
Musila, J. W. \& Yiheyis, Z. (2015). The impact of trade openness on growth: The case of Kenya. Journal of Policy Modeling, 37, 342-354.

Nigeria Industrial Revolution Plan. (2014). The current situation of manufacturing in Nigeria. Nigeria Industrial Revolution Plan- Release 1.0, January. Available at file://C:/Users/ADMIN/Downloads/nirp.pdf

O'Rourke, K. H. (2000). Tariffs and growth in the late 19th century. Economic Journal, 110, 456-483.

Oladipo, O. S. (2011). Does Trade Liberalization Cause Long Run Economic Growth in Mexico? An Empirical Investigation. International Journal of Economics and Finance, 3(3).

Olaifa, F., Subair, K. \& Musa, I. (2013). Trade liberalization and economic growth in Nigeria: A co-integration analysis. Journal of Business, Economics and Finance, 2(3), 43-52.

Oluwaleye, J. (2014). Public policy and trade liberalization in Nigerian economic development. Research on Humanities and Social Sciences, 4(15), 91-95.

Parinduria, R. \& Thangavelu, S. (2013). Trade liberalization, free trade agreements, and the value of firms: Stock market evidence from Singapore. The Journal of International Trade and Economic Development, 22(6), 924-941.

Pesaran, H. M., Shin, Y. \& Smith, R. J. (2001). Bounds Testing Approaches to the Analysis of Level Relationships. Journal of Applied Economics, 3(7), 29-38.

Petreski, M. (2013). Southeastern European trade analysis: A role for endogenous CEFTA-2006? Emerging Markets Finance and Trade,49(5), 26-44.

Safuan, S. (2012). ASEAN economic cooperation: trade liberalization impacts on the national economy. International Journal of Economics and Finance, 4(11), 66-75.

Solow, R. (1956). A contribution to the theory of economic growth. Quarterly Journal of Economics, 70, 65-94.

Sunariyo, Hanani, N., Setiawan, B. \& Syafrial. (2015). Trade Liberalization Impact on Economic Performance of Indonesian Palm Coconut Plantation. Journal of Economics and Sustainable Development, 6(2).

Swan, T. W. (1956). Economic growth and capital accumulation. Economic Record, 32, 334-61.

Thu, T. \& Lee, H. (2015). Assessing the impact of deeper trade reform in Vietnam using a general equilibrium framework. Journal of Southeast Asian Economies, 32(1), 140-62.

Uexkull, E. \& Shui, L. (2014). Implementing the ECOWAS common external tariff challenges and opportunities for Nigeria. World Bank Group. Africa Trade Practice Working Paper Series, 5, 2-40.

Ulaşan, B. (2015). Trade openness and economic growth: Panel evidence. Applied Economics Letters, 22, 163167.

World Development Indicator. (2017). World Bank Database online-version (WDI).

World Integrated Trade Solution. (2017). Database for Tariff and Trade in Nigeria. World Integrated Trade Solution (WITs).

World Trade Organization. (2012). A practical guide to trade policy analysis. Geneva: WTO publications. Retrieved from http//: www.wto.org.

WTO. (2015). Tariffs [Online]. Geneva, Switzerland: World Trade Organization. Available athttps://www.wto.org/english/tratop_e/tariffs_e/tariffs_e.htm

Yahya, Z., Dantama, Y. \& Abdullahi, M. (2013). Relationship between trade liberalization and economic growth: Empirical evidence from Sub-Saharan Africa. African Journal of Social Sciences,3(1), 111-120.

Yanikkaya, H. (2003). Trade openness and economic growth: a cross-country empirical investigation. Journal of Development Economics, 72(1), 57-89.

Yoko, A., Dalin, C., Takahiro, F., Seiha, N. \& Tatsufumi, Y. (2013). Firm dynamics in the Cambodian garment industry: Firm turnover, productivity growth and wage profile under trade liberalization. Journal of the Asia Pacific Economy, 18(1), 51-70.

Yucel, G. (2014). The effects of EU customs union integration on Turkish intra-industry trade. Emerging Markets Journal, 4(1), 17-22. 